DOI: 10.2478/v10141-009-0035-8

\title{
On Virtue in the Context of Sport
}

\author{
Maria Zowisło
}

University School of Physical Education in Cracow, Poland

\begin{tabular}{|c|c|}
\hline & ABSTRACT \\
\hline & 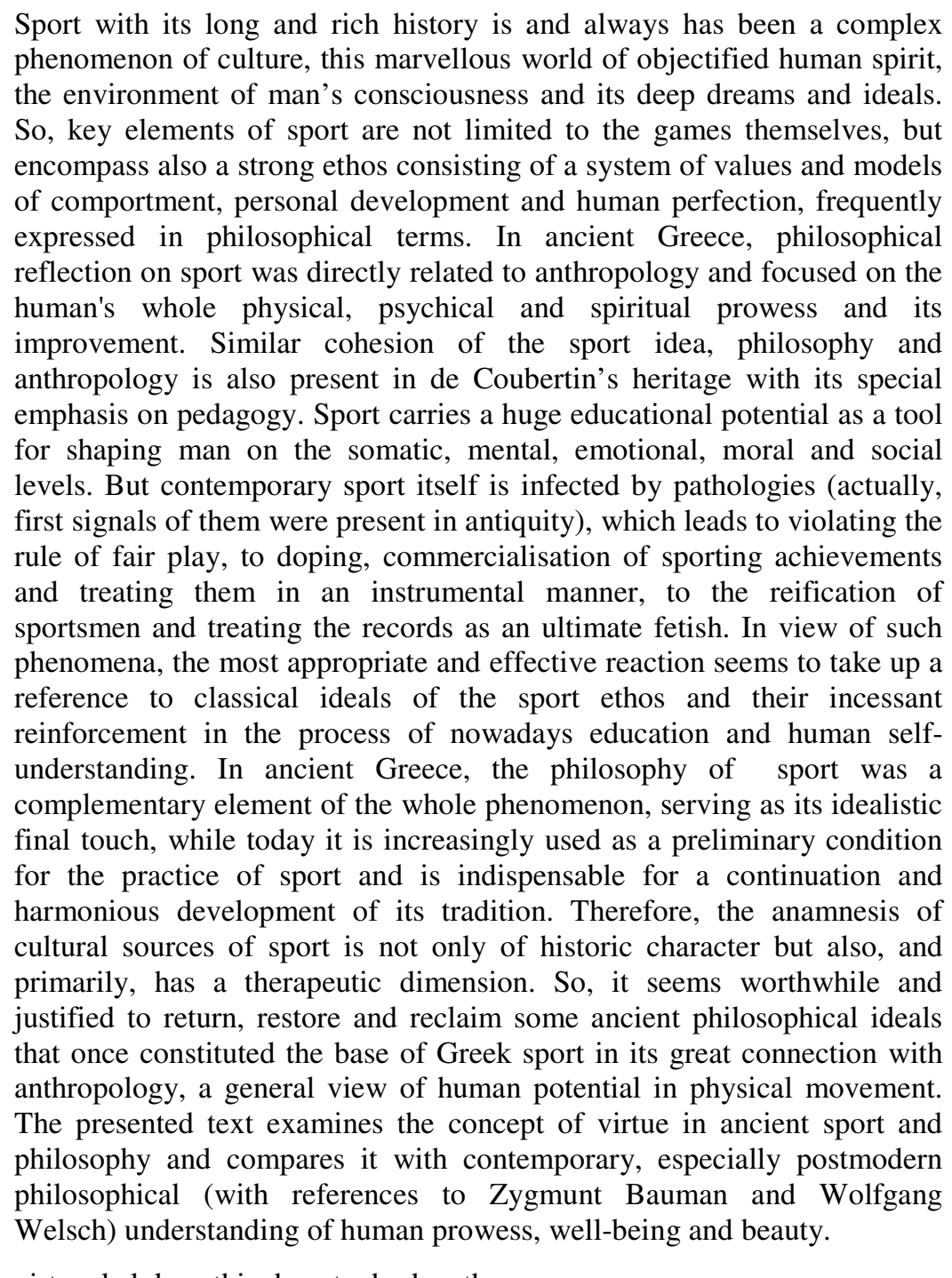 \\
\hline KEYWORDS & virtue, kalokagathia, beauty, body, ethos \\
\hline
\end{tabular}

One of the most fundamental concepts constituting the ethos of sport, staying at the very roots of the sports virtues is an idea of Greek philosophical origin, later restored and adopted by Pierre de Coubertin - it is the idea of kalokakathia. It became a mark of all sport and Olympic enterprises, i.e. training, competition, Olympic Games and especially all discussions taken up by academics bound up with sports interest. But as a representative label, although rooted in the ancient idea, which like all 
profound old ideas being gradually endowed in their stretched evolution with a weightless rhetorical shape, it stays in a great menace to be reduced in its appeal into a single flat mark and literal sign, a mere slogan washed away and devoid of its really vital and stimulating meaning. However, a cathegory of kalokagathia might still be understood by a modern man and sportsman as a considerable values-radiating symbol of human potential and destiny. I am deeply convinced that it depends on hermeneutical, ethical and psychological handing down of this great philosophical tradition not only by philosophers of sport and but by coaches as well. Indeed, it is a great challenge for all people concerned with sport and eager for its vital duration.

The subtle Greek philosophical concept of kalokagathia was the crowning of a long cultural process of Greek paideia, i.e. education which was grounded in a much older idea of arete. This connection with arete, that denoted both physical valiance of human being and man's moral virtue seems to be the best argument for using the concept of kalokagathia by ancient philosophers and modern researchers of sport in describing human mobile creative-dynamic condition and human instinct of sport. I think it is worth taking a historical detour to the ancient Greek roots of Western civilization. Of course many did and do take such a journey: Winckelmann, Goethe, Coubertin and others, but if we take it not only in a sentimental but also a hermeneutical manner as a round trip, it will prove helpful to our modernity (or postmodernity) in coping with its crises.

The assumption that the Homeric tradition was the boundary-post of the Western past is taken for granted, but in fact it was a final flowering of much older pre-Homeric times. But actually with the Homeric poems we meet the first preserved and systematically elaborated general view of the world and man within it that became a base for further great Greek cultural achievements like philosophy, theatre, fine arts, education and among others sporting games. The global psychological vision of the human condition we find in these poems became the ground for the heroic ethos of Homeric warriors that people admire to this day. This ethos was constituted by arete and kalokagathia, the values we are here interested in. Of these two arete seems to be of an older tradition because kalokagathia only has its precisely linguistic expression in Solon's poetry (Dembińska-Siury 1991, p. 77). In spite of this witness we can find the intuition of the sense of kalokagathia strictly bound up with the idea of arete in the Iliad where there existed a conviction that a beautiful bodily appearance of man was an external shape of diverse virtues of the whole personage (Iliad 1946, II 211-277). Tersites, who did not have arete, was ugly and his address was derided. In opposite to him Achilles and Odysseus stood for a paradigm of true warriors who possessed both the virtues as they are depicted by historians and philosophers: the virtue of physical brawn and that of wise language (Krokiewicz 1959, p. 58; Jaeger 1954, p. 30). These two virtues were located in actual parts of the human body: the heart was the organ of passion, fervor, feeling and enthusiasm (Greek thymos and menos), whereas the midriff stood for the organ of Homeric noos and phren, mind and rational ego (Krokiewicz 1959, p. 47). Homer conceived the nature of human being as a collection of half-physiological and half-psychological symbiotic forces. They were the forces of life hence they could not exist after the death of man. There was no place here for the autonomous substantial soul that further founded Pythagoras' and Plato's philosophy, setting up the beginning of the mind-body dualism which then received its classical form in the 17th system of Descartes. Such a dualism was absolutely unfamiliar to the Homeric vision of man that seems to have been a kind of monistic naturalism. Due to this anthropological monism Homer had no problem constructing the bridge from the subjectivity to external world, from psyche to matter, from soul to body. Therefore the educational programme of paideia based on the Homeric ethos of heroic style of living so deeply rooted in the organic wholeness of human condition was very close to the essential sense of kalokagathia as a unity of physical and psychological virtues. As Adam Krokiewicz points out, in Homeric Greece :'The most beautiful virtues of man were those of his heart and his mind. For Greeks they had possessed the extreme charm. The former occured in overcoming 
the weakness of mortal body, in increasing its strength to supernatural range, in victorious ascendancy over rivals and in great fighting deeds, the latter in wise words and supreme pieces of advice" (Krokiewicz 1959, p. 59).

In periods of peace, as it is described in the Oddysey, the warrior state of living was changed to that of sport, enemies of war put on the mask of rivals of sport agon. Partaking in sporting competion was a test and proof of possessing arete. Another way of confirming one's own virtue that appears to be close to the further Calvinist idea of prosperity and welfare is the way of Hesiod's "Works and Days". Here sport competition takes the form of coping with everyday efforts and job. Such activity was available for everybody and we can see that the rivalry of noble warriors was democratically transformed into the rivalry of common people. The apparent sign of man's prowess, strength, beauty and goodness was inhered in the fruits of hard work.

With the appearance of Classical rational thought the conception of arete went alongside the development of the philosophical idea of kalokagathia, and there was considerable interaction between the two. The philosophy of Socrates, Plato and Aristotle introduced a much more complicated notion of the structure of the human being. Man was split into body and soul, matter and form. It is then hardly surprising that in the case of such dualism philosophers were to cope with establishing the order and harmony of different elements of man's nature. And here a new understanding of arete and kalokagathia endowed with strong intellectual and ethical meaning arises. We all know the statement of Socrates that "virtue is knowledge". As W.K.C.Guthrie explains, Socratic man could not be efficient and happy unless he took the trouble to learn a general function (ergon) of human being (Guthrie 1967, p. 9). In such a manner philosophers preserved the practical aspect of arete. What in the Homeric tradition stood for warriors' permanent endeavour to attest their own valour, obtained in Classical Greek philosophy a qualification of intellectual and moral excellence. This excellence was a state of inner harmony, of the balance and proper and just organisation of the three parts of the soul: appetitive (the love of sensual pleasure), passionate (the love of honour and courage - thymos, which in Homer's vision was a power of life) and rational (the love of wisdom hence philosophy itself) (Cornford 1965, p. 80). Each part of the soul has its own cardinal virtue, consecutively: temperance, courage and reason. The upper virtue which holds these three in healthy balance is the virtue of justice. The Platonic theory of the two stages of education we find in his Republic embraces the training of the body and all three parts of the soul. The lower stage of education in which every citizen had to share was a training of the soul and body by means of music and gymnastics. On this level of human initiation to social life kalokagathia meant well-being and beauty of man's completeness. "Musical man" gained the simplicity in a character like the rhythms of musical harmony. The higher level of Plato's paideia which was depicted more precisely in the Symposium was an intellectual training of the Reason, in "turning the eye of the soul away from the phantoms of the cave towards the light of truth" (Cornford 1965, p. 85). Here kalokagathia is concerned not only with the goodness and beauty but also with wisdom and truth. In the Symposium the Mystery of Eros plays a role of educating the passion for the beauty and it is a transforming path from the love of the individual bodily beauty to the love of the Beauty in itself. In the Platonic vision arete and kalokagathia referred to the whole structure of the human being but a great stress is put on a contemplative side of life, although the first stage of paideia stressed also the active and practical aspects of social existence and marked out a great role of gymnastics and shaping the valour and physical skills of body. Even the study of pure philosophy had attained practical aspect - it could help with deducing the rules of political life.

Turning to Aristotle we trace similar dual conception of human virtues: the moral, practical virtues of political life and that of the highest activity of mind, i.e. contemplation. Moral virtues are the effect of using the principle of rational choice lying in the middle point between two extremes. The 
culminant virtue is a virtue of generosity (megalopsychia) and it is a crowning of virtuous social and intellectual life. He who possesses it deserves true reverence and honor. Generous man is a genius who proves his greatness of heart and daimonic character in sternness, friendship and frank feelings (Krokiewicz 1959, pp. 20-23).

The upper values of justice in Plato's and of moderation in Aristotle's thought although marked by intellectualism reveal at the same time the Greek inclination to give everything its proper place within the whole horizon of life and Greek classical dislike of exaggeration. For this reason the ancient civilization was free of any utmost ascetism and puritanical norms. It occurs only with Christianity, although Thomas Aquinas tried to diminish the supranatural Augustinian overtones in Christian philosophy and assimilated Aristotle's realism. The modern Christian thought on sport, for instance that of Salesian origin, relates to Thomism and Neothomism. The ancient ideal of human harmony is discovered again in the Renaissance. In the 18th century epoch of Enlightenment the repeated revival of ancient values took place and it produced several modern educational visions based on the natural laws, like that of J.J.Rousseau. The common base of all these humanistic concepts points to ancient classical holism. This holism was deeply rooted in the Greek predilection for theoretical generalization that brought in effect philosophy and other notable cultural attainments like theatre and sport games. Such phenomena needed a basic distance: philosophy - a distance from external reality; theatre - from individual fate and sport - from the weakness and mortality of the human body and life at large. The fundamental Greek distance was grounded in giving priority to the visual perspective. According to Aristotle theorein means simply visual perception. As Werner Jaeger indicates (Jaeger 1954, p.11) visual perception attains a total embrace of reality. It requires a certain remoteness that enables man to see everything within the global horizon and locate it in the organic wholeness. For this reason the Greek understanding of education was close to artistic perfomance of carving a shape (later the German idea of Bildung) in compliance with a type or standard conceived as a result of general knowledge. Man and his educational shaping were treated as a work of art. Therefore the idea of human perfection was named eudaimonia and was joined with conviction that beauty and valiance of human body should be completed by the goodness and beauty of the soul.

Our present time, still being debated in categories of postmodernity, is void of any classical, general and common foundations enabling people to attain safe and solid canons of guidance and behaviour. Postmodern man is very mobile but his agility lacks any sense of order. It is a nomadic movement in a labyrinth of motley meanings (Deleuze 1973). The postmodern nomad is a homeless wanderer in search of senses. The main cause of this nomadic state lies in a specific mode of experiencing the world. As Zygmunt Bauman points out in his book Body and Violence in the Face of Postmodernity (Bauman 1995, p. 88) the postmodern condition is constituted by privateness, hedonism, subjectivity, relativism, pluralism and fragmentation of senses. The postmodern nomad is not the ancient hero who was moving in the area of kosmos, the world of order, stabile and secure rules, he is first of all a consumer of perceptions and a collector of impressions. His reception of reality is full of impatience and gluttony, his excessive concentration on aesthethic, sensual (in the original sense of aesthetics) impressions and feelings are due to fragmentation of the world experience. The beauty of the world and man is in the service of satisfying the wants of touching and tasting much more than of the sense of seeing. The postmodern human condition occurs to be an ambivalent bond of freedom and captivity, self-reliance and anxieties of solitary self. In new conditions of life it occurs that the simplest and promptest release of this tension lies in easy tangibility of feeling and taste. And tangibility and nearness give everything but total vision! Visual perception, requiring a certain distance and proper perspective, enables man to locate each detail in integrity. None of this applies to the senses of touch and taste. They concentrate on particles. They can offer a pleasure of immediacy and intimacy but they keep afloat on the boundless surface of an infinite experience. Hence a 
postmodern body is described mainly as a body of a gourmet whose most expected and desirable function is fitness. This fitness means first of all receptive skills of sensual provenance. Actually it is too far an echo of Greek arete. All deep philosophical and ethical aspects of ancient arete are lost here, although Bauman emphasizes that postmodern people's solitude brings out new conditions of human responsibility.

Postmodern German philosopher Wolfgang Welsch in his lecture Sport - Viewed Aesthetically and Even as Art (given in 1998 during the XIV. International Congress of Aesthetics) maintaines and tries to demonstrate that contemporary sport passes from the sphere of ethics into the domain of aesthetics (Welsch 2004). This passing is understood by him as a signum temporis of a more general process called by him after American pragmatist Richard Shusterman the aesthetization of life. Today sport is strictly close to art whereas in antiquity it was connected solely with ethics. Moral discipline of the ancients and the postmodern aesthetic cult of beautiful body are conceived by Welsch as two fundamental opposites revealing at the same time historical evolution of sport and its past and present unreconciliable dissimilarities. I think we should argue with such an attitude and our best counterargument lies just in the ancient idea of kalokagathia, the unanimous ethical and aesthetic address to the beauty and good of man and that human great cultural enterprise of sport itself. And the same argument applies to contemporary sport. Because sport engages the human body and its health we shouldn't let it be reduced exclusively to aesthetic and sensual joys and the pleasures of its spectacle. Sport is and should remain much more conservative than art, which can afford vanguard experiments with good and evil.

In modern (or rather postmodern) sport such tendencies of aesthetization lead for instance to putting too much emphasis on a calculable bodily fitness and breaking more and more great records regardless of the physical and psychical possibilities of champions. A record on behalf of a record itself is a great menace for sport we are now witnessing. There is a place for philosophy here. Unfortunately it plays a narrow and increasingly marginal role in contemporary education for sport. Inasmuch as it ceases to function as a universal and essential base of sport, the modern sport relinquishes Pierre de Coubertin's idea of the revival of the Classical Greek humanism. It is fitting to recall here that the presuppositions of the Modern Olympic Sport as Coubertin understood them were of philosophical and educational origin and were related to the ancient Greeks' notions of arete and paideia. The Modern Olympics as a spectacular part of contemporary sport ran and still can run a great chance of being one of the immense phenomena of the New Humanism, provided that they treat sport as a living symbol. And this means reading the sign of sport's human content: man's spiritual efforts to overcome mortality and to maintain dignity in all borderline situations in life (I refer here to Karl Jaspers' understanding of Grenzsituationen) due to courage and bravery of his mind, heart and body. Man's self-confrontation with the mortal and frail contingent condition of human existence always engages the whole structure of man and so far as the sign of sport appeals to man's will, emotions, sensuous sensitivity and intellectual imagination it remains for him a living symbol. In such a perspective sport could be perceived and experienced as one of these great plots of culture like the phenomena discussed by Ernst Cassirer, i.e. language, art, science, myth and religion.

A hermeneutical reflexive return to antiquity seems necessary not only to recall to the modern mind the idea of human integral self-realization and completeness but also to show the original European springs of holism. In fact nowadays holism is a very fashionable slogan but it exists amidst the context of the New Age movement opened to all exotic cultures and their spiritual and religious backgrounds. Postmodernism has exposed culture to multi-culturalism and pluralism but at the same time rendered the Western historical past more exotic than that of any outlandish civilization. It is evident that the most serious crisis of postmodernity touches Western cultural identity. Although the 
lore of exotic cultures deserves our attention and acknowledgement we needn't confine ourselves to its solutions. The simplest way to overcome the Western crises and the healthiest therapy lie in enlivening the wellspring of our own tradition. It is a great task for philosophy and education not to perform it only sentimentally and consequently not to remain in a mere dead museum.

\section{REFERENCES}

Bauman, Z. (1995). Ciało i przemoc $w$ obliczu ponowoczesności. The Body and Violence in the Face of Postmodernity/. Toruń: Uniwersytet im. Mikołaja Kopernika.

Cornford F.M. (1965). Principium Sapientiae. A Study of the Origins of Greek Philosophical Thought. New York: Harper \& Row.

Deleuze, G. (1973). Pensée nomade. In Nietzsche Aujourd'hui? Paris: Union Générale d'Editions.

Dembińska-Siury, D. (1991). Człowiek odkrywa człowieka. O początkach greckiej refleksji moralnej. Man discovers Man. On the Beginnings of Greek Moral Reflection/.Warszawa: Wiedza Powszechna.

Guthrie, W.K.C. (1967). The Greek Philosophers from Thales to Aristotle. London: Methuen \& Co. LTD.

Homer, (1946). Iliad. London and Cambridge, Mass: Harvard University Press.

Jaeger, W. (1954). Paideia. Die Formung des Griechischen Menschen, Bd. 1. Berlin: Walter de Gruyter\& Co.

Krokiewicz, A. (1959). Moralność Homera i etyka Hezjoda. /Homer's Morality and Hesiod's Ethics/. Warszawa: Pax.

Welsch, W. (2004). Sport: Ästhetisch betrachtet-und sogar als Kunst? In „Kunstforum”, Band 169. 